\title{
FoxO3a is Essential for the Antiproliferative and Apoptogenic Effects of Sunitinib in MDA-MB231 Cell Line
}

\author{
HESHAM M. KORASHY, OSAMAH M. BELALI, MUSHTAQ A. ANSAR and NAIF O. ALHARBI \\ Department of Pharmacology and Toxicology, College of Pharmacy, \\ King Saud University, Riyadh, Kingdom of Saudi Arabia
}

\begin{abstract}
Background: Sunitinib (SUN), a tyrosine kinase inhibitor, is a promising treatment for triple-negative breast cancer (TNBC), the most aggressive and fast-growing type of breast cancer. Yet, the protective effect of SUN against TNBC is poorly investigated and the role of Forkhead box type $O$ (FOXO3a) transcription factor is still unknown. Materials and Methods: Cell proliferation was evaluated using the MTT assay. The mRNA and protein expression of apoptotic, oxidative stress and cell cycle genes were determined by realtime polymerase chain reaction (RT-PCR) and western blot analyses, respectively. Percentage of the apoptotic cells were determined by flow cytometry. The role of FOXO3a was knock-downed using siRNA. Results: SUN caused suppression of MDA-MB231 cell growth associated with induction of apoptosis, cell cycle arrest, oxidative stress markers and FOХOЗ a gene. Importantly, silencing of FOXO3a mRNA using siRNA significantly rescued MDA-MB231 cells from SUN-induced cell-proliferative arrest. Conclusion: SUN inhibits TNBC MDA-MB231 cell proliferation through activation of $\mathrm{FOXO3a}$ expression.
\end{abstract}

Breast cancer has emerged as one of the most widespread and lethal forms of cancers. Almost one million new cases of breast cancer are identified and more than 410,000 patients die each year worldwide (1). In that, approximately 180,000 and 130,000 new cases are diagnosed every year in Europe and USA, respectively. Latin America and Australia are also suppliers of the greatest number of cases of breast cancer. The high incidence, complexity and economic cost

Correspondence to: Hesham M. Korashy, Ph.D., Department of Pharmacology and Toxicology, College of Pharmacy, King Saud University, P.O. Box 2529, Riyadh 11461, Kingdom of Saudi Arabia. Tel: +966 1677183, Fax: +966 14677200, e-mail: hkorashy@ksu.edu.sa

Key Words: Sunitinib, MDA-MB231 cells, cyclin D, FOXO3a, oxidative stress, apoptosis. of the treatment make breast cancer one of the most relevant health problems in the society. Triple-negative breast cancer (TNBC) is the most aggressive and fast growing type of breast cancer that is resistant to most chemotherapy with very high rate of recurrence and poor survival rate and prognosis. Thus, identifying and discovering more effective treatment strategies aimed at TNBC are warranted.

One of those promising treatments for TNBC is tyrosine kinase inhibitors (TKIs). TKIs are small molecules able to pass through the cell membrane and exert their antitumor activity through inhibiting the phosphorylation of intracellular domain of receptor of tyrosine kinases (RTK) (2). This is followed by modulation of several downstream signaling cascades, such as phosphatidylinositol 3-kinase/akt pathway (PI3K/Akt), which results in an increase in cell proliferation, metastasis, angiogenesis and decrease of apoptosis (2). One of the downstream targets of the $\mathrm{PI} 3 \mathrm{~K} /$ Akt signaling pathway is a nuclear transcription factor known as forkhead box class O3a (FOXO3a) (3). FOXO3a plays a crucial role in regulating multiple target genes implicated in several biological processes, such as cell proliferation, cell cycle progression (4, 5), cell differentiation, oxidative stress, tissue homeostasis, angiogenesis and apoptosis (6). In this regard, experimental studies have reported that inactivation of FOXO3a promotes cell transformation and tumor progression, whereas activation of FOXO3a prevents tumor growth in vivo (3), suggesting that FOXO3a may serve as a direct or indirect target for cancer therapy.

A cross-talk between RTK and FOXO3a has been reported previously where activation of RTK by its legends targets PI3K/Akt pathway leading to inhibition of FOXO transcriptional activity through its phosphorylation. In the nucleus, the phosphorylated FOXO3a binds to 14-3-3 protein, which results in translocation of the complex out of the nucleus to the cytoplasm where FOXO3a proteins will be ubiquitinated and then targeted for protein degradation (6). This cross-talk is supported by several previous studies showing that the antiproliferative activity of dasatinib, a TKI, 
Table I. Primers sequences used for real-time polymerase chain (RT-PCR) reactions.

\begin{tabular}{lll}
\hline Gene & $5^{\prime} \rightarrow 3^{\prime}$ Forward primer & $5^{\prime} \rightarrow 3^{\prime}$ Reverse primer \\
\hline CASP3 & CGCAGACCTTGTGATATTCCAG & CGTTTCTTCCATCCTTCCAGG \\
$P 53$ & ATGGCCTCCCTGTACGACATC & TGTTGCGCTCAATCTCCTCCT \\
GSTa1 & TTGATGTTCAGCAAGTGCC & CACCAGCTTCATCCCATCAAT \\
FCND1 & ATGGCGGTGAGTGTCAGGAT \\
ACTB & GATAGCCTTCGACCCAAGCA & CTGGCTCAAGCACAACTTGG \\
\hline
\end{tabular}

against primary chronic myeloid leukemia CD341 cells is mediated by the reactivation of FOXO1, 3a and 4 (7). In addition, it has been previously reported that dephosphorylating and nuclear localization of FOXO3a are mediating the inhibitory effect of TKI gefitinib on breast cancer cell BT474 proliferation (8).

Among these TKIs, sunitinib (SUN) is a multi-targeted inhibitor of tyrosine kinase receptors, including vascular endothelial growth factor receptor (VEGFR), fetal liver tyrosine kinase receptor 3 (FLT3) and platelet-derived growth factor receptor (PDGFR) $(9,10)$. SUN has shown an antitumor activity in several preclinical breast cancer models, both alone and in combination with chemotherapeutic agents $(11,12)$. In addition, It has been reported that SUN significantly inhibits the migration and cell proliferation of different breast cancer cell lines (13). However, the effect of SUN on TNBC cells and specifically the role of FOXO3a transcription factor have not been fully investigated. In the present study, we examined whether SUN effects on cell proliferation, apoptosis, cell cycle arrest and oxidative stress in a TNBC cell line model (MDA-MB231) is mediated through FOXO3a signaling pathway.

\section{Materials and Methods}

Materials. Sunitinib malate was obtained from Toronto Research Chemicals (Toronto, ON, Canada). 2, 7-dichlorodihydrofluorescein diacetate (DCFH-DA) and 3-(4, 5-Dimethylthiazol-2-yl)-2,5diphenyltetrazolium bromide (MTT) were purchased from Sigma Chemical Co. (St. Louis, MO, USA). TRIzol reagent, Dulbecco's modified Eagle's medium (DMEM), annexin V-FITC and propidium iodide (PI) were purchased from Invitrogen Co. (Grand Island, NY, USA). High Capacity cDNA Reverse Transcription kit, SYBR ${ }^{\circledR}$ Green PCR Master Mix and PCR 96-well optical reaction plates were purchased from Applied Biosystems (Foster city, CA, USA). Forward and reverse primers of the target genes were purchased from Integrated DNA technologies (IDT, Coralville, IA, USA). Acrylamide, $\quad N^{\prime} N^{\prime}$ 'bis-methylene-acrylamide, ammonium persulphate, nitrocellulose membrane $(0.45 \mu \mathrm{m})$, sodium dodecyl sulfate (SDS), and $N, N, N^{\prime}, N$ '-tetramethylethylenediamine (TEMED) were purchased from Bio-Rad Laboratories (Hercules, CA, USA). Primary antibodies against target proteins, horseradish peroxidase (HRP)-conjugated secondary antibodies, small interfering RNA
(siRNA) against FOXO3a and transfection reagents were purchased from Santa Cruz Biotechnology, Inc. (Santa Cruz, CA, USA). Chemiluminescence Western blot detection kits were obtained from Merck Millipore (Billerica, MA, USA). All other chemicals were purchased from Fisher Scientific Co. (Toronto, ON, Canada).

Cell culture and treatment. Triple-negative breast cancer MDAMB231 cell line (ATCC HTB-26 ${ }^{\circledR}$ ) was obtained from American Type Culture Collection (Rockville, MD, USA). Cells were maintained in DMEM with phenol red supplemented with $10 \%$ fetal bovine serum and antibiotic-antimycotic Gibco ${ }^{\circledR}$ (Grand Island, NY, USA). Cells were grown in $75-\mathrm{cm}^{2}$ tissue culture flasks at $37^{\circ} \mathrm{C}$ under a $5 \% \mathrm{CO}_{2}$ humidified environment.

The cells were seeded in 12- and 6-well cell culture plates in DMEM culture media for RNA and protein assays, respectively. In all experiments, cells were treated for the indicated time intervals in serum-free media with three increasing concentrations of SUN that were selected based on MTT assay. SUN solutions were prepared fresh just before each experiment and dissolved in distilled water.

Cell proliferation assay. MDA-MB231 cell viability and proliferation in response to SUN was determined by measuring the capacity of reducing enzymes present only in viable cells to convert MTT to formazan violet crystals as described previously (14). The percentage of cell proliferation was calculated relative to control wells designated as $100 \%$ viable cells, where $\%$ cell proliferation= $\left(\mathrm{A}_{\text {treated }}\right) /\left(\mathrm{A}_{\text {control }}\right) \times 100 \%$.

RNA extraction and cDNA synthesis. TRIzol reagent (Invitrogen ${ }^{\circledR}$ ) was utilized to isolate total cellular RNA according to the manufacturer's instructions. The quality and quantity of isolated RNA were assessed by measuring the absorbance at $260 \mathrm{~nm}$ and maintaining 260/280 ratio $\sim 2.0$. First strand cDNA was synthesized using the High-Capacity cDNA reverse transcription kit (Applied Biosystems ${ }^{\circledR}$ ) according to the manufacturer's instructions and as described previously (15).

Quantification of $m R N A$ expression by real-time polymerase chain reaction $(R T-P C R)$. The mRNA expression of target genes was quantified using RT-PCR by subjecting the resulting cDNA to PCR amplification using QuantStudio 6 Flex RT-PCR System (Applied Biosystems ${ }^{\circledR}$ ) using SYBR Green Universal Master mix as described previously (16). Human primers for caspase-3 (CASP3), P53, cyclin D1 (CCND1), glutathione s-transferase A1 (GSTa1), $F O X O 3 a$ and $\beta$-actin $(A C T B)$ genes (Table I) were purchased from Integrated DNA technologies (IDT). The fold change in the level of these genes between treated and untreated cells was corrected by 
the levels of $\beta$-actin. The RT-PCR data were analyzed using the relative gene expression (i.e., $\Delta \Delta \mathrm{Ct}$ ) method, as described and explained previously (17) using the following equation: fold change $=2^{-\Delta(\Delta \mathrm{Ct})}$, where $\Delta \mathrm{Ct}=\mathrm{Ct}_{(\text {target })}-\mathrm{Ct}_{(\beta \text {-actin) }}$ and $\Delta(\Delta \mathrm{Ct})=\Delta \mathrm{Ct}_{(\text {treated })}{ }^{-}$ $\Delta \mathrm{Ct}_{\text {(untreated) }}$.

Determination of caspase-3 activity. The activity of caspase-3 was assessed using the colorimetric CaspACE assay by Biovision ${ }^{\circledR}$ (Mountain View, CA, USA) according to the manufacturer's instructions and as described previously (18). Approximately $30 \mu \mathrm{g}$ protein was incubated with $200 \mu \mathrm{M}$ enzyme-specific colorimetric caspase-3 substrate I, acetyl-Asp-Glu-Val-Asp p-nitroanilide (AcDEVD-pNA) at $37^{\circ} \mathrm{C}$ for $2 \mathrm{~h}$. Caspase- 3 activity was assessed by measuring absorbance at a wavelength of $405 \mathrm{~nm}$ with a plate reader from Bio-Tek Instruments (Winooski, VT, USA).

Western blot analysis. Total protein from MDA-MB231 cells was extracted as described previously (19). The protein concentrations were quantified using Direct Detect ${ }^{\circledR}$ Infrared Spectrometer, EMD Millipore Co. (Billerica, MA, USA). Western blot analysis was performed using a previously described method (19). Briefly, 25-35 $\mu \mathrm{g}$ of protein from each treatment group was separated by $10 \%$ sodium dodecyl sulfate (SDS)-polyacrylamide gel electrophoresis (PAGE) and then electrophoretically transferred to nitrocellulose membrane. Protein blots were then blocked overnight at $4^{\circ} \mathrm{C}$ in blocking solution, then washed several times with TBS-Tween-20 before being incubated with primary antibodies against target proteins overnight at room temperature in TBS solution followed by incubation with a peroxidase-conjugated IgG secondary antibodies for $2 \mathrm{~h}$ at room temperature. The bands were visualized and then quantified by $\mathrm{C}-\mathrm{DiGi}^{\mathrm{t}}{ }^{\circledR}$ Blot Scanner, LI-COR Biosciences (Lincoln, NE, USA) using the enhanced chemiluminescence method according to the manufacturer's instructions (Merck Millipore, Billerica, MA, USA).

Flow cytometric analysis of apoptosis. The percentage of cells undergoing apoptosis/necrosis was determined by flow cytometry using annexin V staining as described previously (20). Briefly, MDA-MB231 cells were treated for $24 \mathrm{~h}$ with test compounds; thereafter, the medium was removed and cells were washed with cold PBS before trypsinization. The collected cells were centrifuged at $300 \times g$ for $5 \mathrm{~min}$ and then re-suspended with $0.5 \mathrm{ml}$ PBS. Cells were then stained with annexinV-FITC/PI and immediately analyzed on a Beckman Coulter FC500 Cytomics Benchtop Flow Cytometer, Beckman Coulter Inc. (Indianapolis, IN, USA) for apoptotic and necrotic populations.

Analysis of cell cycle phases distribution and progression. Cell cycle distribution was analyzed using flow cytometry as described previously (20). Briefly, MDA-MB231 cells, seeded in 6-well culture plates, were treated for $24 \mathrm{~h}$ with test compounds. Thereafter, cells were trypsinized, harvested and fixed in $1 \mathrm{ml}$ $70 \%$ cold ethanol in test tubes and incubated at -20 for $30 \mathrm{~min}$. After incubation, cells were centrifuged at 1,500 rpm for $5 \mathrm{~min}$ and cell pellets were re-suspended in $500 \mu \mathrm{l} \mathrm{PI}(10 \mu \mathrm{g} / \mathrm{ml})$ containing $300 \mu \mathrm{g} / \mathrm{ml}$ RNase (Sigma-Aldrich, St. Louis, MO, USA). Then cells were incubated on ice for $30 \mathrm{~min}$ and filtered through a $53-\mu \mathrm{m}$ nylon mesh. Cell cycle distribution was calculated from 10,000 cells with ModFit LTTM software, Becton Dickinson (San Jose, CA, USA) using FACScaliber (Becton Dickinson).

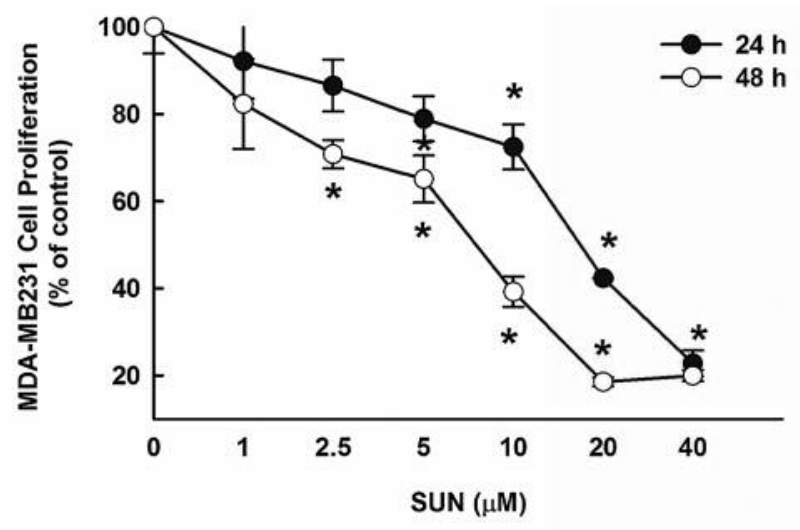

Figure 1. Effect of sunitinib (SUN) on MDA-MB231 cell proliferation and viability. MDA-MB231 cells were treated for $24 \mathrm{~h}$ and $48 \mathrm{~h}$ with various concentrations of SUN and cell viability was determined using the MTT assay. Values are presented as \% of the control (mean \pm SEM, $n=6) . * p<0.05$ compared to control $(0 \mu M)$.

Determination of reactive oxygen species (ROS) production. The redox status of the MDA-MB231 cells was determined by flow cytometry. Briefly, MDA-MB231 cells treated with test compounds were incubated with DCFH-DA $(5 \mu \mathrm{M})$ for $1 \mathrm{~h}$. Cells were washed in PBS and centrifuged at $100 \times g$ for $5 \mathrm{~min}$ and suspended in sheath fluid. PI $(5 \mu \mathrm{g} / \mathrm{ml})$ was added to the samples immediately before analysis. The green DCF-fluorescence (10,000 events) was analyzed in the FL-1 channel (Excitation $\lambda 488$; Emission $\lambda 535$ ) and PI fluorescence was analyzed in the FL-2 channel.

FOXO3a silencing with small interfering RNA. Silencing of FOXO3a gene was determined by transfecting the cells with FoxO3a small interfering RNA (siRNA) according to manufacture instruction (Santa Cruz Biotechnology, Inc.). Briefly, 70\% confluent MDA-MB231cells were transfected for $7 \mathrm{~h}$ with FOXO3a siRNA. Thereafter, the cells were washed and then incubated with $10 \mu \mathrm{M}$ concentration of SUN for $24 \mathrm{~h}$. Finally, FOXO3a, CASP3, CCND1 and GSTa1 mRNA levels were quantified by RT-PCR.

Statistical analysis. The comparative analysis of the results from various experimental groups with their corresponding controls was performed using Sigma Stat ${ }^{\circledR}$ for Windows, Systat Software, Inc. (San Jose, CA, USA). One-way analysis of variance (ANOVA) followed by Student-Newman-Keul's test was carried out to assess which treatment groups showed a significant difference from the control group. The differences were considered significant when $p<0.05$.

\section{Results}

Effect of SUN treatment on cell growth and proliferation. To determine the antiproliferative effect and concentrations of SUN against MDA-MB231 cell growth, the cells were exposed for $24 \mathrm{~h}$ and $48 \mathrm{~h}$ to increasing concentrations of SUN (0, 1, 2.5, 5, 10, 20 and $40 \mu \mathrm{M})$; thereafter, cell proliferation assay was performed using the MTT method. 
A

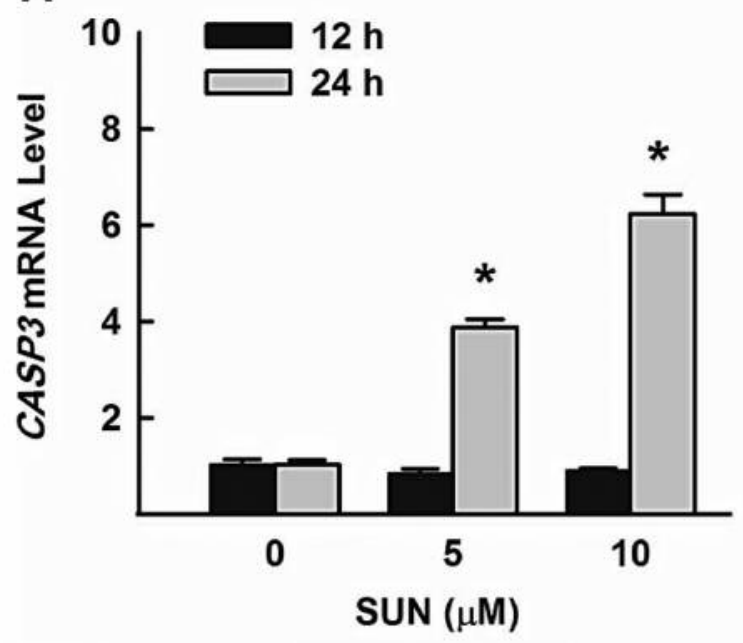

C

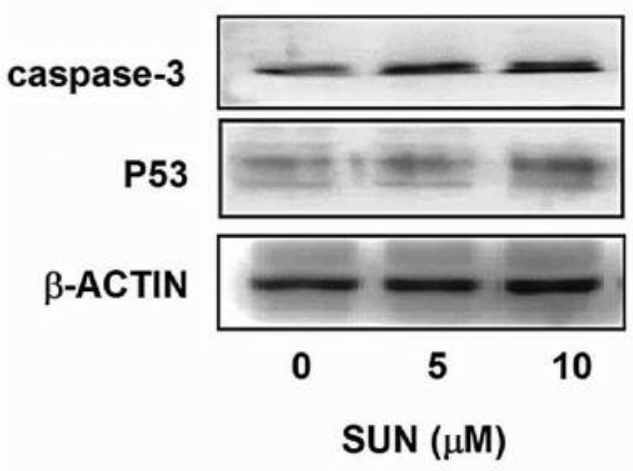

B
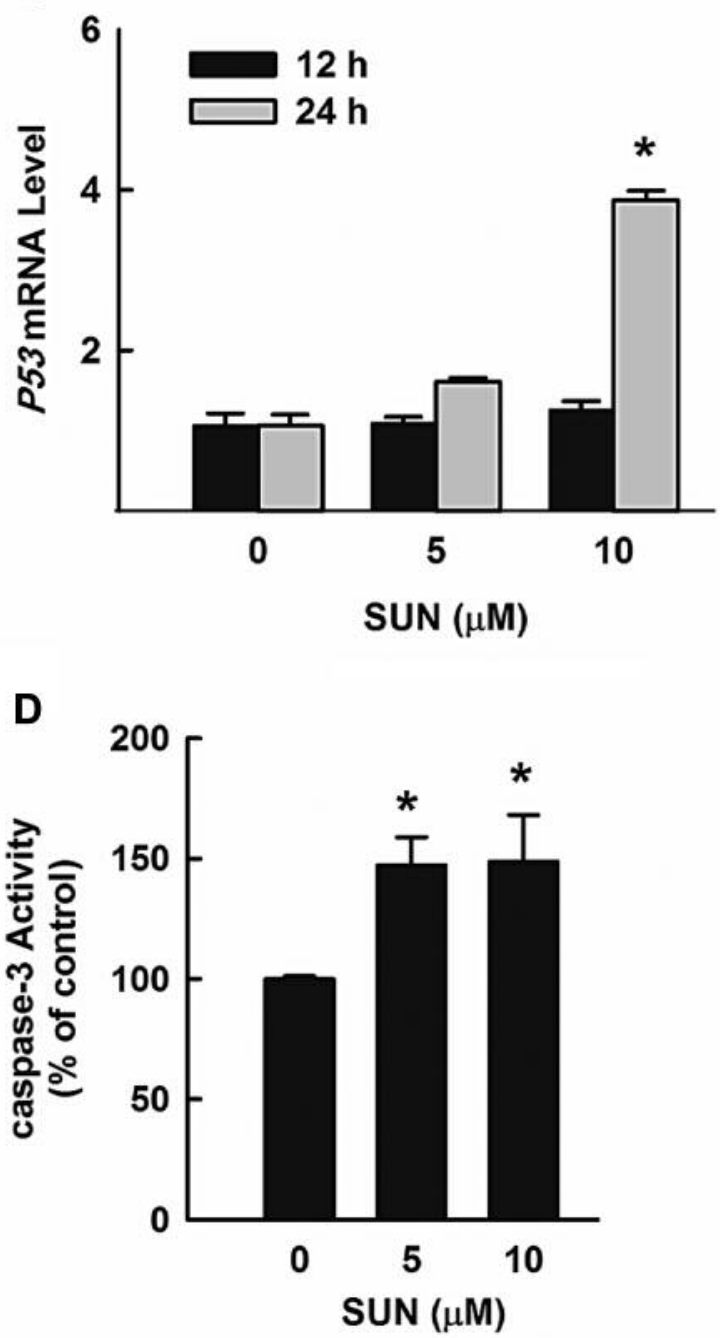

Figure 2. Effect of sunitinib (SUN) treatment on apoptotic markers in MDA-MB231 cells. (A and B) MDA-MB231 cells were treated for 12 and $24 \mathrm{~h}$ with SUN $(0,5$ and $10 \mu \mathrm{M})$. The mRNA levels of caspase-3 (CASP3) and P53 genes were quantified by RT-PCR and normalized to actin housekeeping gene. Duplicate reactions were performed for each experiment and the values represent mean of fold change $\pm S E M(n=6) . * p<0.05$ compared to control $(0 \mu M)$. (C) MDA-MB231 cells were treated for $24 \mathrm{~h}$ with $S U N(0,5$ and $10 \mu M)$ and the caspase-3 and P53 protein expression levels were determined by western blot analysis. The intensity of protein bands was quantified relative to the signals obtained for $\beta$-actin protein, using C-DiGit ${ }^{\circledR}$ blot scanner. (D) MDA-MB231 cells were treated for $24 \mathrm{~h}$ with $S U N(0,5$ and $10 \mu \mathrm{M})$. Thereafter, caspase-3 activity was determined using the CaspACE Kit. The values represent mean of percentage of change $\pm S E M .(n=6) . * p<0.05$ compared to control $(0 \mu M)$.

Results presented in Figure 1 show that all SUN concentrations up to $2.5 \mu \mathrm{M}$ did not significantly affect cell viability and proliferation (Figure 1). However, SUN concentrations 5, 10 and $20 \mu \mathrm{M}$ significantly decreased cell viability by approximately $21 \%, 57 \%$ and $58 \%$, in the $24-\mathrm{h}$ incubation period, respectively, whereas, $48 \mathrm{~h}$ incubation with SUN 5, 10 and $20 \mu \mathrm{M}$ greatly reduced the cell viability by approximately $35 \%, 61 \%$ and $82 \%$, respectively. On the other hand, the highest concentration $(40 \mu \mathrm{M})$ markedly inhibited cell proliferation by more than $85 \%$. Based on these findings,
SUN concentrations 5 and $10 \mu \mathrm{M}$ and the 24-h time interval were utilized in all subsequent experiments.

Effect of SUN treatment on the expression levels of apoptotic genes. To determine the capacity of SUN to modulate the expression of apoptotic genes, concentration- and timedependent studies were conducted. For this purpose, MDAMB231 cells were incubated for $12 \mathrm{~h}$ and $24 \mathrm{~h}$ with increasing concentrations of $\operatorname{SUN}(0,5$ and $10 \mu \mathrm{M})$. Thereafter, the mRNA expression levels of two apoptotic 
A

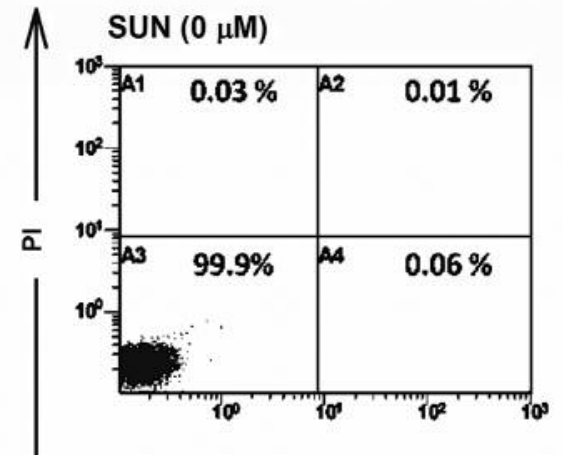

B
SUN $(5 \mu \mathrm{M})$

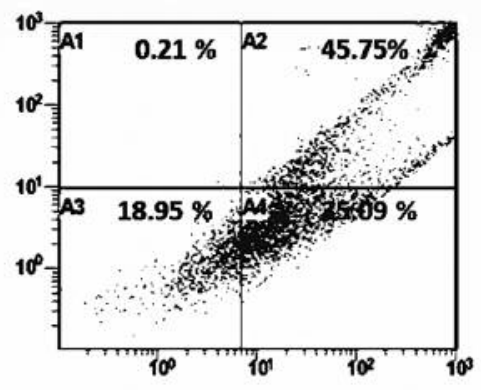

Annexin V/FITC
SUN $(10 \mu M)$

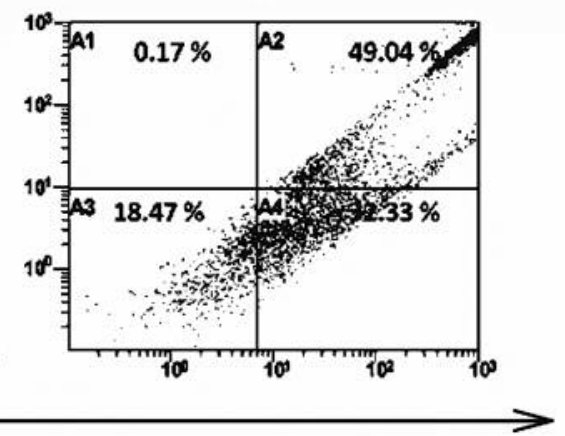

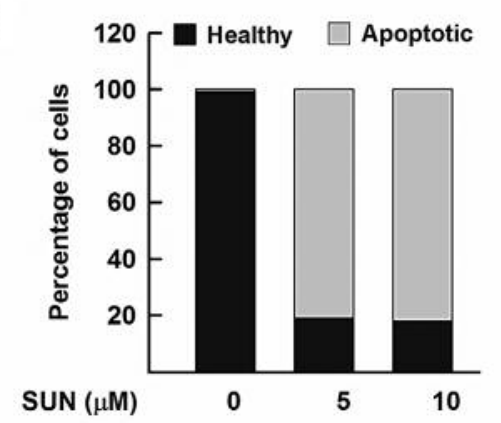

genes, CASP3 and P53, were quantified by RT-PCR. Figure $2 \mathrm{~A}$ and $\mathrm{B}$ shows that incubation of SUN for $12 \mathrm{~h}$ has insignificant effect on CASP3 and P53 mRNA levels, whereas SUN treatment for $24 \mathrm{~h}$ significantly increased the mRNA expression levels of CASP3 and P53 in a concentration-dependent manner. The maximum induction levels of CASP3 (6.5-fold) and P53 (4-fold) mRNA were observed at the highest concentration tested, i.e. $10 \mu \mathrm{M}$.

To further determine whether changes in the mRNA levels of $C A S P 3$ and $P 53$ resulted in alteration at their protein levels, MDA-MB231 cells were incubated for $24 \mathrm{~h}$ with SUN (0, 5 and $10 \mu \mathrm{M})$. Thereafter, caspace- 3 and P53 protein levels were determined by western blot analysis. In a manner similar to mRNA results, Figure $2 \mathrm{C}$ shows that SUN (5 and $10 \mu \mathrm{M}$ ) significantly induced caspase-3 protein levels by approximately 2- and 4-fold, respectively. On the other hand, only SUN $10 \mu \mathrm{M}$ concentration was able to increase the protein expression levels of P53 by 2-fold, as compared to control, and normalized the $\beta$-ACTIN expression levels.

Effect of SUN treatment on the enzymatic activity of caspase3 gene. In order to explore whether increased mRNA and protein levels of caspase- 3 is translated into functional protein, caspase- 3 activity of MDA-MB231 cells treated for $24 \mathrm{~h}$ with SUN was determined calorimetrically using the
Figure 3. Effect of sunitinib (SUN) treatment on percentage of apoptotic MDA-MB231cells. MDA-MB231 cells were treated for $24 \mathrm{~h}$ with SUN $(0,5$ and $10 \mu M)$; thereafter, the percentage of cells undergoing apoptosis/necrosis was determined using annexinV-FITC/propidium iodide (PI). The cells were immediately analyzed on a Beckman Coulter FC500 Cytomics Benchtop Flow Cytometer.

CaspACE Kit (BioVision ${ }^{\circledR}$ ). Figure 2D shows that SUN induced caspase- 3 activity by the two concentrations to approximately $150 \%$ at the highest concentration tested as compared to control.

Effect of SUN treatment on the percentage of MDA-MB231 cells that underwent apoptosis/necrosis. To further explore whether the SUN-induced apoptotic genes and cell death is due to increased apoptotic and/or necrotic cell population, the percentage of MDA-MB231 cells that underwent apoptosis/necrosis in response to increasing concentrations of SUN $(0,5$ and $10 \mu \mathrm{M})$ was determined by staining the cells with annexin V-FITC and PI using flow cytometry. Figure 3 shows that $99.9 \%$ of untreated cells were healthy; however, treatment of the cells with SUN significantly increased the percentage of cells that experienced early apoptosis from $0.06 \%$ (control cells) to $32 \%$ and $42 \%$ in response to 5 and $10 \mu \mathrm{M}$ SUN, respectively. In addition, late apoptotic cells were significantly increased from $0.01 \%$ (control cells) to approximately $49 \%$ and $42 \%$ in response to SUN 5 and $10 \mu \mathrm{M}$, respectively.

Effect of SUN treatment on MDA-MB231 cell-cycle phase and distribution. To determine whether the inhibitory effect of SUN on MDA-MB231 cells proliferation and growth is attributed to cell cycle arrest, we tested this hypothesis by 


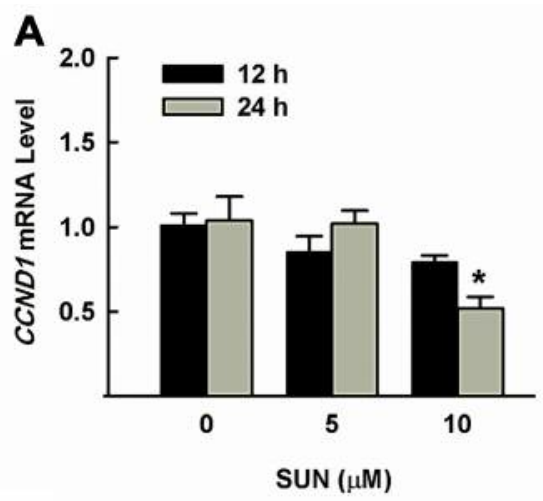

B

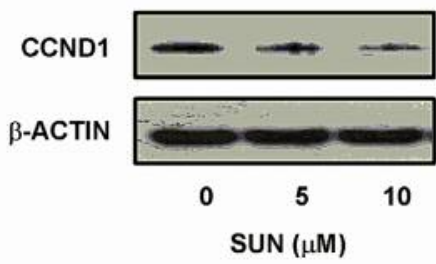

C
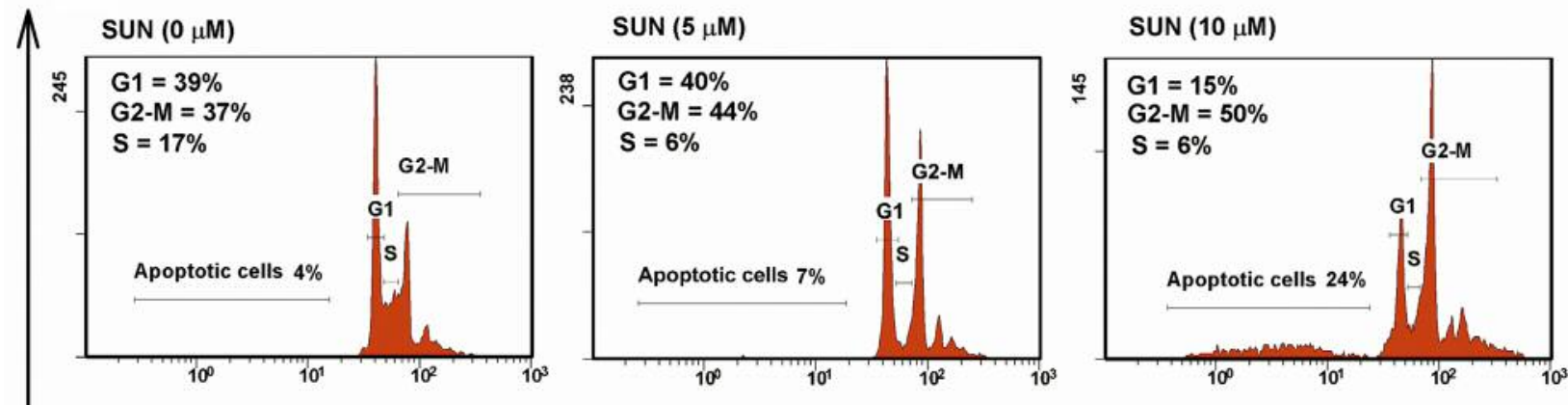

PI Fluoresence

Figure 4. Effect of sunitinib (SUN) treatment on cell cycle genes and phases. (A) MDA-MB231 cells were treated for $12 \mathrm{~h}$ and $24 \mathrm{~h}$ with SUN (0, 5 and $10 \mu M)$. Cyclin D1 (CCND1) mRNA levels were quantified by RT-PCR. Values represent mean $\pm S E M .(n=6) . *^{*}<0.05$ compared to control $(0 \mu M)$. $(B)$ $M D A-M B 231$ cells were treated for $24 \mathrm{~h}$ with $S U N(0,5$ and $10 \mu M)$ and cyclin D1 (CCND1) protein expression levels were determined by Western blot analysis. One of three representative experiments is shown. Values are presented as mean $\pm S E M, n=3 . * p<0.05$ compared to control $(0 \mu M)$. $(C)$ MDA-MB231 cells were treated for $24 \mathrm{~h}$ with SUN $(0,5$ and $10 \mu \mathrm{M})$ before being stained with PI containing RNase. Changes in cell-cycle phases and distribution were determined by Beckman Coulter FC500 Cytomics Benchtop Flow Cytometer.

two approaches. First, we measured the mRNA and protein expression levels of cyclin D1 (CCND1), as cell cycle proliferator marker, after treating the cells with increasing concentrations of SUN for $12 \mathrm{~h}$ and $24 \mathrm{~h}$. RT-PCR analysis shows that $12 \mathrm{~h}$ treatment with SUN did not significantly alter the mRNA expression of CCND1; however, after $24 \mathrm{~h}$ treatment, SUN significantly inhibited CCND1 mRNA levels only at the higher concentration of $10 \mu \mathrm{M}$ by approximately $50 \%$ (Figure 4A). At the protein level, western blot analysis shows that treatment with SUN $10 \mu \mathrm{M}$ for $24 \mathrm{~h}$ significantly inhibited CCND1 levels, in a manner similar to results obtained at the mRNA levels (Figure 4B).

The second approach was to examine the effect of SUN on cell cycle phase profile and distribution using flow cytometry. For this purpose, MDA-MB231 cells treated for $24 \mathrm{~h}$ with SUN were stained with PI and the cell-cycle phases were determined. Figure 4C shows that treatment with SUN 5 and $10 \mu \mathrm{M}$ caused an increase in the percentage of cells in the $\mathrm{G}_{2} / \mathrm{M}$ population to approximately 44 and $50 \%$, respectively, as compared to control $37 \%$. In addition, the increased cell population at the $\mathrm{G}_{2} / \mathrm{M}$ was accompanied with a decrease of cell population in the $\mathrm{G}_{0} / \mathrm{G}_{1}$ phase only at a higher concentration $(10 \mu \mathrm{M})$ by approximately $60 \%$, whereas cells in the $\mathrm{S}$ phase were significantly decreased by both concentrations by $65 \%$. Furthermore, a significant increase in the percentage of apoptotic cells was also observed in cells treated with SUN in a concentration-dependent manner.

Effect of SUN treatment on the oxidative stress. The role of oxidative stress in the SUN-induced cell death was assessed first by measuring the percentage of ROS generation in response to SUN treatment. For this purpose, MDA-MB231 cell treated for $24 \mathrm{~h}$ with $\operatorname{SUN}(0,5$ and $10 \mu \mathrm{M})$ were stained with DCFH-DA and the percentage of DCF formation, as ROS indicator, was detected by flow cytometry. Figure 5A shows that SUN significantly increased the percentage of ROS production in MDA-MB231cells in a concentration-dependent manner by approximately $17 \%$ and $31 \%$, respectively. 

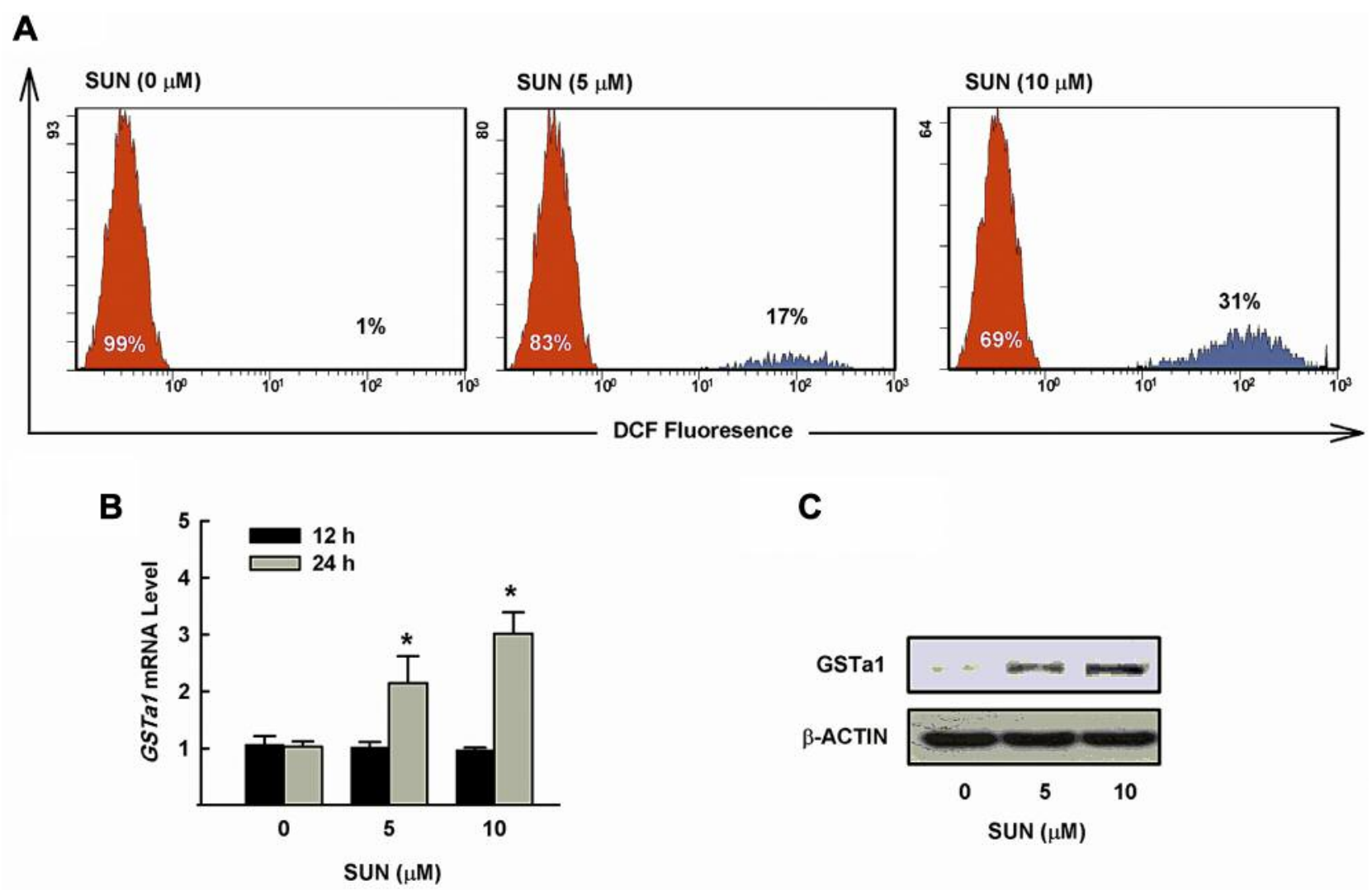

Figure 5. Effect of sunitinib (SUN) treatment on oxidative stress. MDA-MB231 cells were treated for $24 \mathrm{~h}$ with SUN $(0,5$ and $10 \mu M)$ and thenstained with DCFH-DA. Thereafter, DCF fluorescence production was determined by Beckman Coulter FC500 Cytomics Benchtop Flow Cytometer. (B) MDA-MB231 cells were treated for 12 and $24 \mathrm{~h}$ with various concentrations of SUN $(0,5$ and $10 \mu M)$. GSTal mRNA levels were quantified by $R T$-PCR and normalized to $\beta$-ACTIN housekeeping gene. The values represent mean of fold change $\pm S E M .(n=6) .{ }^{*} p<0.05$ compared to control $(0 \mu M)$. (C) MDA-MB231 cells were treated for $24 \mathrm{~h}$ with $S U N(0,5$ and $10 \mu M)$ and GSTa1 protein expression levels were determined by western blot analysis. One of three representative experiments is shown.

Second, we measured the changes in the expression of oxidative stress mediated gene, GSTal, in response to SUN. Thus, GSTal mRNA and protein expression levels were determined by RT-PCR and Western blot analyses, respectively, after $12 \mathrm{~h}$ and $24 \mathrm{~h} \mathrm{SUN}$ treatment. Figure 5B and $\mathrm{C}$ shows that $12 \mathrm{~h} \mathrm{SUN}$ treatment did not alter the expression of GSTal genes; however, 24 h SUN treatment induced GSTal mRNA and GSTal protein levels in a concentration-dependent manner. For example, SUN 5 and $10 \mu \mathrm{M}$ induced GSTal mRNA by approximately 2- and 3fold, respectively (Figure 5B).

Effect of SUN treatment on the gene expression levels of FOXO3a transcription factor. To determine the effect of SUN on FOXO3a gene expression, MDA-MB231cells were incubated for 12 and $24 \mathrm{~h}$ with increasing concentrations of SUN $(0,5$ and $10 \mu \mathrm{M})$. Thereafter, FOXO3a mRNA and protein levels were quantified by RT-PCR and Western blot analyses, respectively. Figure 6A clearly shows that SUN treatment for 12 and $24 \mathrm{~h}$ resulted in a significant induction of FOXO3a mRNA in a concentration- and time-dependent manner. The onset of induction was observed at $12 \mathrm{~h}$ and maintained for at least $24 \mathrm{~h}$. The maximum induction (4fold) was observed at $10 \mu \mathrm{M}$ SUN after 12 and $24 \mathrm{~h}$ treatment (Figure 6A). At the protein level, in manner similar to mRNA result, SUN 5 and $10 \mu \mathrm{M}$ significantly induced FOXO3a protein level by approximately 2 - and 4 -fold, respectively, as compared with the control (Figure 6B).

Effect of FOXO3a silencing on SUN-mediated effects in MDA-MB231 cells. To investigate the potential role of FOXO3a in mediating SUN effects on apoptosis, cell cycle and oxidative stress genes, we transfected MDA-MB231 cells with either a FOXO3a-specific siRNA or control negative siRNA before incubation with a single concentration of SUN $(10 \mu \mathrm{M})$. Thereafter, the mRNA levels 


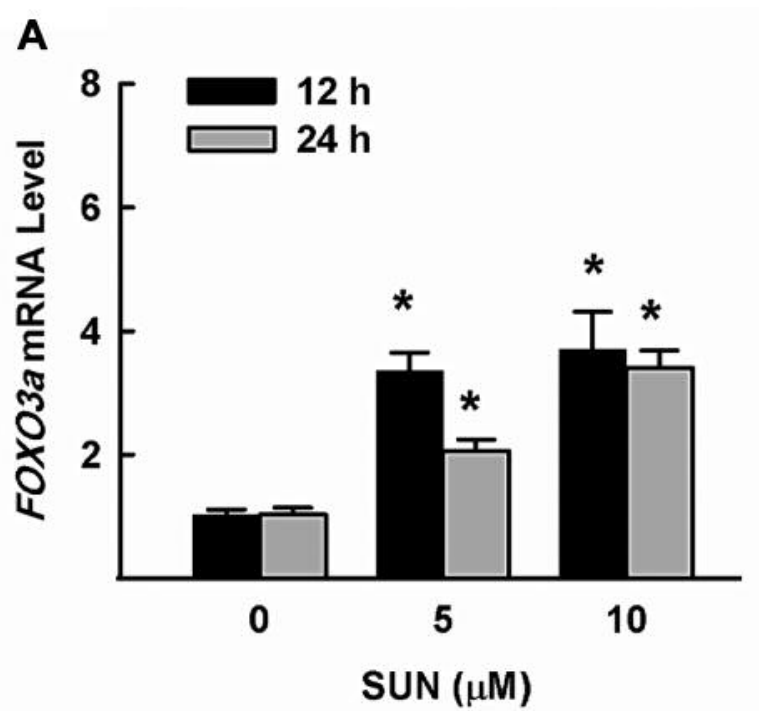

B

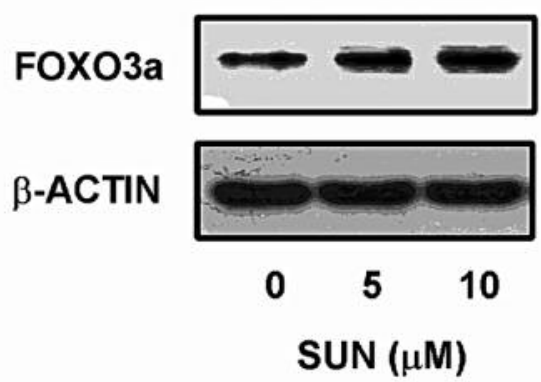

Figure 6. Effects of sunitinib (SUN) treatment on FOXO3a mRNA and protein levels. (A) MDA-MB231 cells were treated for 12 and $24 \mathrm{~h}$ with SUN; thereafter, FOXO3a mRNA expression levels were quantified by $R T-P C R .{ }^{*} p<0.05$ compared to control $(0 \mu M)$. (B) MDA-MB231 cells were treated for $24 h$ with SUN $(0,5$ and $10 \mu M)$. Thereafter, FOXO3a protein expression levels were determined by Western blot analysis. One of three representative experiments is shown.

of FOXO3a, CASP3, CCNDI and GSTal were determined by RT-PCR. Initially, RT-PCR analysis showed that the FOXO3a-specific siRNA knocked down the basal expression of FOXO3a mRNA level by approximately $60 \%$, whereas the SUN-induced FOXO3a mRNA levels were knocked down by approximately $82 \%$ (Figure 7A).

To show that FOXO3a has an essential role in controlling SUN-mediated effects, we examined the effect of FOXO3a silencing on SUN-mediated effect on apoptotic, cell cycle and oxidative stress markers. Figure 7B shows that treatment of control siRNA-transfected cells with SUN $10 \mu \mathrm{M}$ resulted in a dramatic increase in CASP3 mRNA levels (6-fold), whereas knockdown of $F O X O 3 a$ significantly inhibited the SUN-induced CASP 3 mRNA by approximately $58 \%$ (to $2.5-$ fold). On the other hand, the SUN-mediated inhibition of cell cycle proliferative gene $C C N D 1(50 \%)$ was partially restored in MDA-MB231 cells transfected with FOXO3a targeting siRNA (Figure 7C). Similarly, induction of GSTal mRNA levels in response to SUN (4-fold) was completely blocked by $\mathrm{FOXO3a}$ knockdown (Figure 7D).

\section{Discussion}

The present study demonstrates the first evidence that activation of FOXO3a transcription factor is essential for the SUN-mediated TNBC MDA-MB231 cell growth inhibition, apoptosis, cell cycle arrest and oxidative stress. This is supported by the following findings; a) inhibition of MDAMB231 cell growth and proliferation by SUN; b) induction of apoptotic gene markers (caspase-3 and P53) at mRNA, protein and activity levels associated with increased percentage of apoptotic cells; c) inhibition of cell proliferation gene CCND1 and arrested MDA-MB231 cells in the $\mathrm{G}_{2} / \mathrm{M}$ phase in the cellcycle machinery; d) induction of oxidative stress marker (GSTa1) at the mRNA and protein levels associated with increased ROS production; e) induction of FOXO3a at the mRNA and protein levels in a concentration-dependent manner; and f) FOXO3a gene silencing caused restoration of SUN-mediated effect on apoptosis, cell cycle arrest and oxidative stress, thus suggesting that FOXO3a gene is essential for antiproliferative and apoptogenic effects of SUN.

The current study aimed to investigate the potential antiproliferative and apoptotic effects of SUN against human TNBC and explore the involvement of FOXO3a transcription factor using human TNBC MDA-MB231 cells as an in vitro model. In this study, the proliferation assay showed that SUN had a concentration- and time-dependent effect since it significantly inhibited MDA-MB231 cell proliferation and growth, which points to the potential antiproliferative effect of SUN in TNBC MDA-MB231 cells. The in vitro concentrations of SUN used in this study ( 5 and $10 \mu \mathrm{M})$ were maintained within the therapeutic range of plasma concentration reported in humans. For example, human subjects given $80 \mathrm{mg}$ SUN for the treatment of advanced renal cell carcinoma had a mean plasma concentrations range from 0.5 to $1 \mu \mathrm{M}$ (21). Although the current in vitro SUN concentrations were above the feasible therapeutic plasma levels in humans, this can be attributed to the excessive concentrations of glucose, fetal bovine serum and growth factor(s) in culture media that stimulate cell growth and promote breast cancer aggression (22). In addition, the presence of oncogenic mutations in the cell culture system may account for the reduced efficacy and elevated concentration of SUN required to elicit cellular responses in vitro to achieve the anti-cancer effects of SUN (23). These data, collectively, provide a high degree of in vivo relevance to the results arising from the concentrations of SUN that might be attained during cancer treatment. Therefore, the present results still seem clinically relevant. 

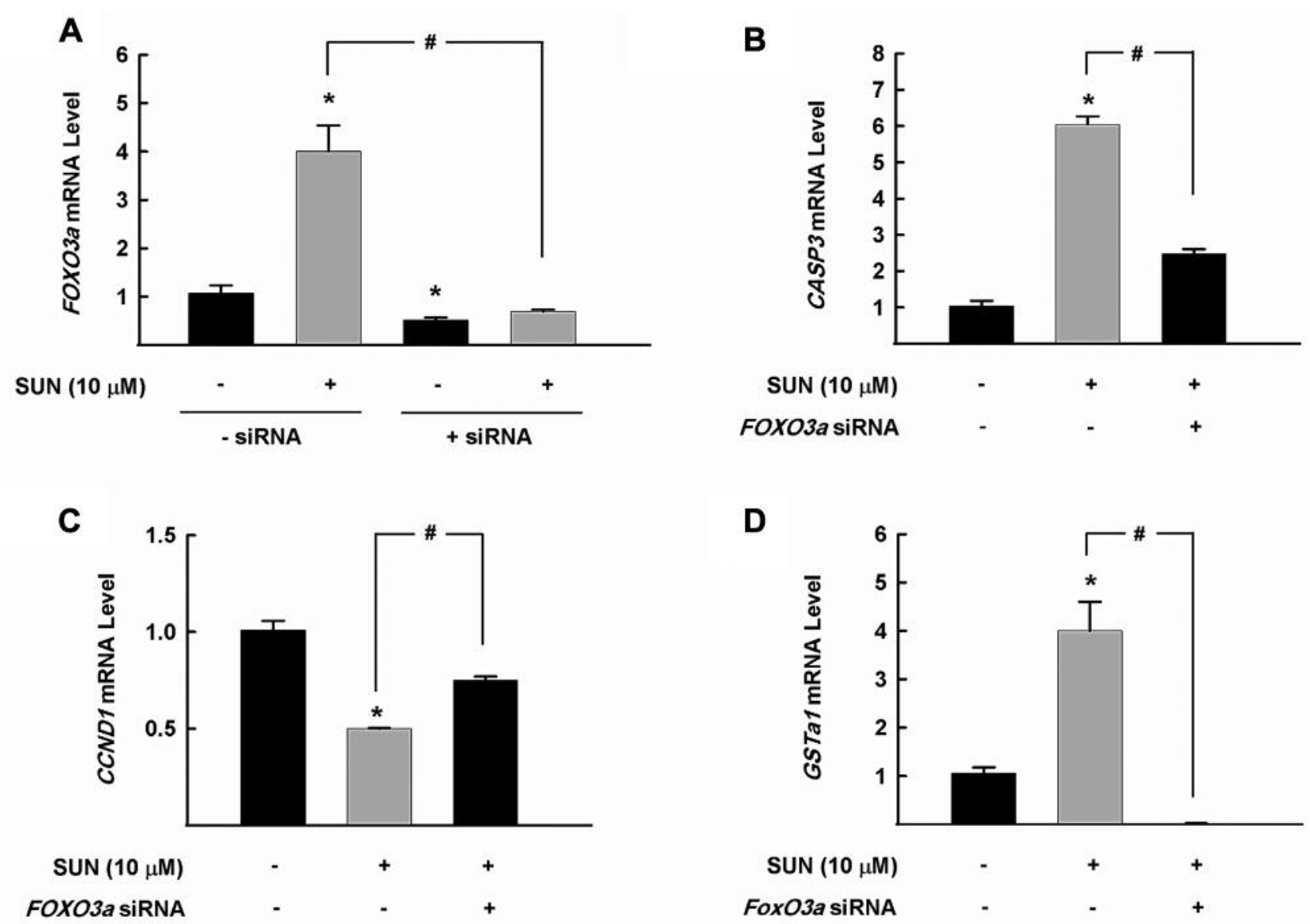

Figure 7. Effects of FOXO3a knockdown on FOXO3a, CASP3, CCND1 and GSTa1 mRNA expression. MDA-MB231 cells were transfected with either FOXO3a siRNA or negative siRNA before being incubated with SUN $10 \mu \mathrm{M}$ for $24 \mathrm{~h}$. (A) FOXO3a, (B) caspase-3 (CASP3), (C) cyclin D1 (CCND1) and (D) GSTa1 mRNA levels were quantified by RT-PCR and normalized to $\beta$-ACTIN housekeeping gene. The values represent mean of fold change \pm SEM. $(n=6) . * p<0.05$ compared to control $(0 \mu M)$ and $\# p<0.05$ compared to corresponding siRNA treatment.

Several cellular and molecular pathways are known to mediate cell proliferation, such as apoptosis, cell cycle and oxidative stress status (24). Thus, the role of each pathway as a proposed mechanism for the antiproliferative effect of SUN- was investigated. Apoptosis is an important regulatory pathway for cell survival and death. In the current study, the role of apoptosis in SUN-induced MDA-MB231 cell growth inhibition was addressed by two approaches. First, induction of apoptotic markers, CASP3 and P53, gene expression at the mRNA, protein and activity levels in response to SUN. In agreement with our observations, it has been reported that genistein, a protein kinase inhibitor, and xanthorrhizol, a natural sesquiterpenoid compound, inhibit MDA-MB231 cell proliferation through induction of apoptosis $(25,26)$. On the other hand, activation of P53, a well-known tumor suppressor gene and regulator for apoptosis cell cycle (27), is highlighting the involvement of apoptosis in SUN-induced cell growth inhibition. This is supported by the fact that P53 becomes inactive in several types of human cancer (28-30). In our work, SUN induced P53 mRNA and protein in a concentration-dependent manner, suggesting that SUN induces P53 to suppress several genes that are implicated in transcriptional regulation, cell cycle progression and proliferation $(30,31)$. The second approach, to address the role of apoptosis, is the ability of SUN to increase the percentage of MDA-MB231 cells that underwent apoptosis/necrosis in a concentration-dependent manner. The current results not only confirm that SUN is a potent inducer of apoptosis but also triggers events leading to apoptotic cell death. Similarly, it has been shown that treatment of human breast cancer cells (MCF7) with various inducers of apoptosis, such as resveratrol (32), significantly inhibited the cell growth and proliferation without causing morphological changes (33).

Cell cycle is a critical process by which a cell copies itself exactly; thus, deregulation of the cell cycle is a common finding in malignant tumors and cancer development (34). 


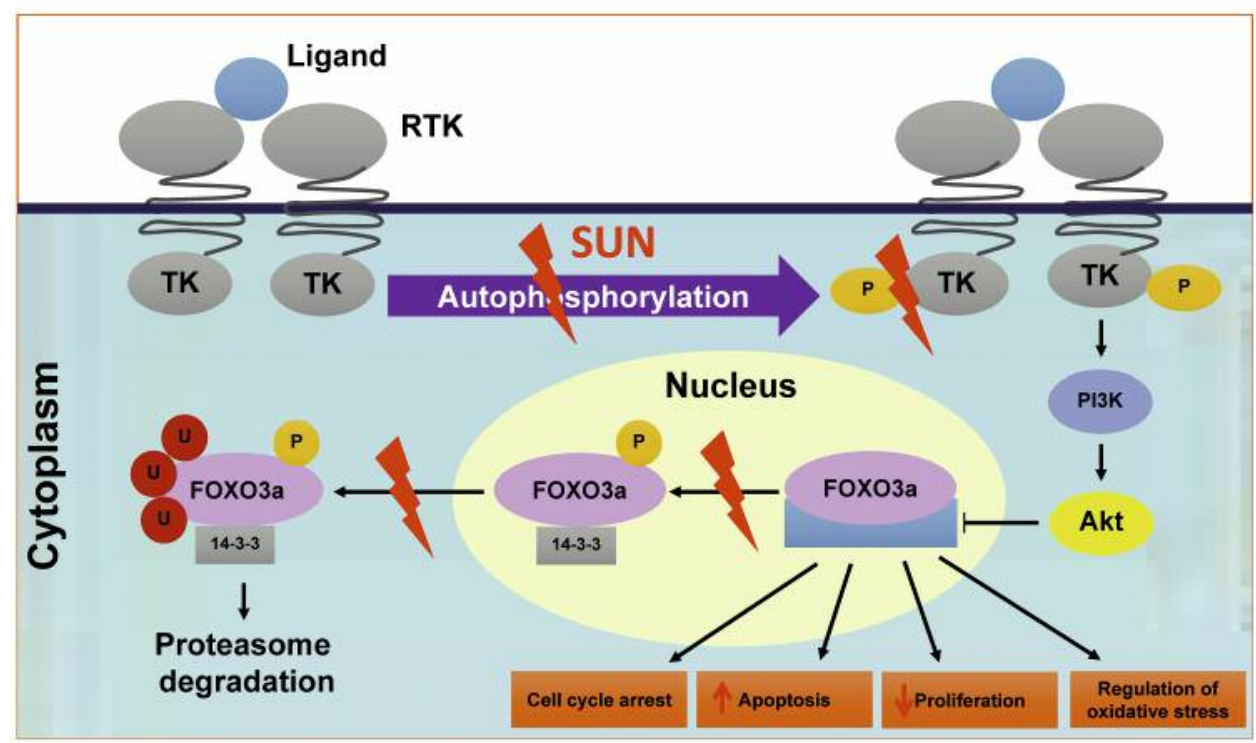

Figure 8. Proposed mechanisms of the antiproliferative and apoptotic effects of sunitinib (SUN) in MDA-MB231 cells.

Cell-cycle arrest and apoptosis are closely related events in which mitosis and apoptosis are showing similarity in their morphological properties, whereas apoptosis is regulated by genes that are involved in cell cycle progression (particularly P53) and disruption of cell cycle progression that may ultimately lead to apoptotic death $(24,35,36)$. Therefore, the involvement of cell cycle in SUN-mediated cell growth inhibition was supported by the ability of SUN to induce P53 mRNA and protein levels that slowed down the proliferation of MDA-MB231 cells as evidenced by the inhibition of the cell cycle proliferation gene CCDN1, the most widely studied cyclin in breast tumor $(35,37)$, and subsequent arrest of MDA-MB231 cell cycle progression in the $G_{2} / M$ phase. These observations are in agreement with previous studies showing that gefitinib, a TKI, induced $\mathrm{G}_{2} / \mathrm{M}$ arrest in breast cancer (38) and other cancer cell lines (39). In contrast, resveratrol induced $S$-phase cell cycle arrest in different breast cancer cell lines (40). Taken together, down-regulation of cyclin cell cycle proliferation genes by anticancer drugs may be a helpful strategy to kill breast cancer cells.

Oxidative stress is a disturbance in the balance between production of free radicals and ROS and their elimination, including antioxidants and detoxifying enzymes. It has been reported that oxidative stress plays an important role in the regulation of apoptotic process through the release of mitochondrial cytochrome $\mathrm{c}$ with subsequent activations of caspase-9 and caspase-3 (41). The ability of SUN to induce oxidative stress, in the current study, is evidenced by increased GSTa1 mRNA and protein GSTa1 expression levels, as well as production of ROS. These results are supported by previous observations showing that induction of oxidative stress genes in breast carcinoma cells inhibits proliferation and induces apoptosis and cell-cycle arrest (42-44) through activation of ubiquitin-dependent proteasome degradation of cyclin D1 (42) or activation of mitochondrial/caspase pathway (45).

Perhaps, the most interesting observations, in the current study, were the ability of SUN to induce FOXO3a mRNA and protein levels in a concentration- and time-dependent manner, which was accompanied with a proportional increase in apoptosis, cell cycle arrest and oxidative stress. More importantly, the early onset of FOXO3a induction as early as $12 \mathrm{~h}$ after SUN treatment and the 24-h onset of induction of CASP3, CCND1 and GSTa1 suggest that FOXO3a might be the driving force for SUN-mediated effect. Consistent with our observations, several TKIs, such as lapatinib (46) and gefitinib (8), have been shown to induce FOXO3a expression in different breast cancer cell lines. In addition, previous studies demonstrated that overexpression of FOXO3a activates caspase-3-mediated apoptosis $(8,47,48)$ and down-regulates CCND1-mediated cell cycle (48). However, it is unclear whether the increase of FOXO3a is directly responsible for the induction of apoptosis and cell cycle arrest in MDA-MB231 cells. To address this question, we examined whether knockdown of the FOXO3a gene using siRNA technology could block SUN-mediated effects. The results of this study showed that silencing of FOXO3a gene partially, but significantly, restored SUN-mediated induction of apoptosis and cell cycle arrest, whereas completely restored SUN-induced oxidative stress. These results clearly indicate that FOXO3a is 
essential for the antiproliferative and apoptotic effects of SUN. Similarly, it has been reported before that knockdown of FOXO3a gene blocked gefitinib-induced breast cancer cell proliferation arrest (38).

In conclusion, we proposed here that SUN treatment of the TNBC MDA-MB231 cell line targets the transcription factor FOXO3a to mediate apoptosis, cell cycle arrest and oxidative stress. In that, silencing of the FOXO3a expression by siRNA, at least partially, rescued MDA-MB231 cells from undergoing apoptosis, growth inhibition, cell cycle arrest in response to SUN, thus suggesting that the induction of FOXO3a expression has a direct role in mediating SUN effects (Figure 8). The current study not only reveals that the transcription factor FOXO3a could be a useful early biomarker for the effectiveness of chemotherapeutic agents but also suggests that SUN could be a promising chemotherapeutic agent against resistant TNBC.

\section{Conflicts of Interest}

There are no financial or other interests with regard to this manuscript that might be construed as a conflict of interest. All Authors are aware of and agree to the content of the manuscript and their being listed as an Author on the manuscript.

\section{Acknowledgements}

This Project was funded by the National Plan for Science, Technology and Innovation (MAARIFAH), King Abdulaziz City for Science and Technology, Kingdom of Saudi Arabia, Award Number (12-MED3131-02) and (272/36/TA).

\section{References}

1 Reeves GK, Travis RC, Green J, Bull D, Tipper S, Baker K, Beral V, Peto R, Bell J, Zelenika D and Lathrop M: Incidence of breast cancer and its subtypes in relation to individual and multiple low-penetrance genetic susceptibility loci. JAMA 304 : 426-434, 2010.

2 Hartmann JT, Haap M, Kopp H-G and Lipp H-P: Tyrosine kinase inhibitors-a review on pharmacology, metabolism and side effects. Curr Drug Metab 10: 470-481, 2009.

3 Jiang Y, Zou L, Lu W-Q, Zhang Y and Shen A-G: Foxo3a Expression Is a Prognostic Marker in Breast Cancer. PloS one 8: e70746, 2013.

4 Medema RH, Kops GJ, Bos JL and Burgering BM: AFX-like Forkhead transcription factors mediate cell-cycle regulation by Ras and PKB through p27kip1. Nature 404: 782-787, 2000.

5 Dijkers PF, Medema RH, Pals C, Banerji L, Thomas NSB, Lam EW-F, Burgering BM, Raaijmakers JA, Lammers J-WJ and Koenderman L: Forkhead transcription factor FKHR-L1 modulates cytokine-dependent transcriptional regulation of p27KIP1. MCN 20: 9138-9148, 2000.

6 Carter ME and Brunet A: FOXO transcription factors. Current Biology 17: R113-R114, 2007.

7 Pellicano F, Scott MT, Helgason GV, Hopcroft LEM, Allan EK, Aspinall-O'Dea M, Copland M, Pierce A, Huntly BJ and
Whetton AD: The anti-proliferative activity of kinase inhibitors in chronic myeloid leukaemia cells is mediated by FOXO transcription factors. Stem Cells 2014.

8 Krol J, Francis RE, Albergaria A, Sunters A, Polychronis A, Coombes RC and Lam EW-F: The transcription factor FOXO3a is a crucial cellular target of gefitinib (Iressa) in breast cancer cells. Mol Cancer Ther 6: 3169-3179, 2007.

9 Abrams TJ, Lee LB, Murray LJ, Pryer NK and Cherrington JM: SU11248 inhibits KIT and platelet-derived growth factor receptor $\beta$ in preclinical models of human small cell lung cancer. Mol Cancer Ther 2: 471-478, 2003.

10 Mendel DB, Laird AD, Xin X, Louie SG, Christensen JG, Li G, Schreck RE, Abrams TJ, Ngai TJ and Lee LB: In vivo antitumor activity of SU11248, a novel tyrosine kinase inhibitor targeting vascular endothelial growth factor and platelet-derived growth factor receptors Determination of a pharmacokinetic/p harmacodynamic relationship. CCR 9: 327-337, 2003.

11 Murray LJ, Abrams TJ, Long KR, Ngai TJ, Olson LM, Hong W, Keast PK, Brassard JA, O'Farrell AM and Cherrington JM: SU11248 inhibits tumor growth and CSF-1R-dependent osteolysis in an experimental breast cancer bone metastasis model. Clin Exp Metastas 20: 757-766, 2003.

12 Abrams TJ, Murray LJ, Pesenti E, Holway VW, Colombo T, Lee LB, Cherrington JM and Pryer NK: Preclinical evaluation of the tyrosine kinase inhibitor SU11248 as a single agent and in combination with "standard of care" therapeutic agents for the treatment of breast cancer. Mol Cancer Ther 2: 1011-1021, 2003.

13 Stalker L, Pemberton J and Moorehead RA: Inhibition of proliferation and migration of luminal and claudin-low breast cancer cells by PDGFR inhibitors. Cancer Cell Int 14: 89, 2014.

14 Korashy HM and El-Kadi AO: Modulation of TCDD-mediated induction of cytochrome P450 1A1 by mercury, lead, and copper in human HepG2 cell line. Toxicol In Vitro 22: 154-158, 2008.

15 Korashy HM, Anwar-Mohamed A, Soshilov AA, Denison MS and El-Kadi AO: The p38 MAPK inhibitor SB203580 induces cytochrome P450 1A1 gene expression in murine and human hepatoma cell lines through ligand-dependent aryl hydrocarbon receptor activation. Chem Res Toxicol 24: 1540-1548, 2011.

16 Maayah ZH, Ghebeh H, Alhaider AA, El-Kadi AO, Soshilov AA, Denison MS, Ansari MA and Korashy HM: Metformin inhibits 7,12-dimethylbenz[a] anthracene-induced breast carcinogenesis and adduct formation in human breast cells by inhibiting the cytochrome P4501A1/aryl hydrocarbon receptor signaling pathway. Toxicol Appl Pharmacol 284: 217-226, 2015.

17 Livak KJ and Schmittgen TD: Analysis of relative gene expression data using real-time quantitative PCR and the 2(-Delta Delta C(T)) Methods 25: 402-408, 2001.

18 Korashy HM, Maayah ZH, Abd-Allah AR, El-Kadi AO and Alhaider AA: Camel milk triggers apoptotic signaling pathways in human hepatoma HepG2 and breast cancer MCF7 cell lines through transcriptional mechanism. J Biomed Biotechnol 2012: 593195, 2012.

19 Korashy HM and El-Kadi AO: Differential effects of mercury, lead and copper on the constitutive and inducible expression of aryl hydrocarbon receptor (AHR)-regulated genes in cultured hepatoma Hepa 1c1c7 cells. Toxicology 201: 153-172, 2004.

20 Shashi B, Jaswant S, Madhusudana RJ, Kumar SA and Nabi QG: A novel lignan composition from Cedrus deodara induces apoptosis and early nitric oxide generation in human leukemia Molt-4 and HL-60 cells. Nitric Oxide 14: 72-88, 2006. 
21 Hasinoff BB, Patel D and O'Hara KA: Mechanisms of myocyte cytotoxicity induced by the multiple receptor tyrosine kinase inhibitor sunitinib. Mol Pharmacol 74: 1722-1728, 2008.

22 Wahdan-Alaswad R, Fan Z, Edgerton SM, Liu B, Deng XS, Arnadottir SS, Richer JK, Anderson SM and Thor AD: Glucose promotes breast cancer aggression and reduces metformin efficacy. Cell Cycle 12: 3759-3769, 2013.

23 Will Y, Dykens JA, Nadanaciva S, Hirakawa B, Jamieson J, Marroquin LD, Hynes J, Patyna S and Jessen BA: Effect of the multitargeted tyrosine kinase inhibitors imatinib, dasatinib, sunitinib, and sorafenib on mitochondrial function in isolated rat heart mitochondria and H9c2 cells. Toxicol Sci 106: 153-161, 2008.

24 Evan GI and Vousden KH: Proliferation, cell cycle and apoptosis in cancer. Nature 411: 342-348, 2001.

$25 \mathrm{Li} \mathrm{Y,} \mathrm{Upadhyay} \mathrm{S,} \mathrm{Bhuiyan} \mathrm{M} \mathrm{and} \mathrm{Sarkar} \mathrm{FH:} \mathrm{Induction} \mathrm{of}$ apoptosis in breast cancer cells MDA-MB-231 by genistein. Oncogene 18: 3166-3172, 1999.

26 Cheah YH, Nordin FJ, Tee TT, Azimahtol HLP, Abdullah NR and Ismail Z: Antiproliferative property and apoptotic effect of xanthorrhizol on MDA-MB-231 breast cancer cells. Anticancer Res 28: 3677-3689, 2008.

27 Cui Q, Tashiro S, Onodera S, Minami M and Ikejima T: P53mediated cell cycle arrest and apoptosis through a caspase-3independent, but caspase-9-dependent pathway in oridonintreated MCF-7 human breast cancer cells. Acta Pharmacologica Sinica 28: 1057-1066, 2007.

28 Hollstein M, Sidransky D, Vogelstein B and Harris CC: p53 mutations in human cancers. Science 253: 49-53, 1991.

29 Hussain SP and Harris CC: Molecular epidemiology of human cancer: contribution of mutation spectra studies of tumor suppressor genes. Cancer Res 58: 4023-4037, 1998.

30 Brodsky MH, Nordstrom W, Tsang G, Kwan E, Rubin GM and Abrams JM: Drosophila p53 binds a damage response element at the reaper locus. Cell 101: 103-113, 2000.

31 Fridman JS and Lowe SW: Control of apoptosis by p53. Oncogene 22: 9030-9040, 2003.

32 Kim YA, Choi BT, Lee YT, Park DI, Rhee SH, Park KY and Choi YH: Resveratrol inhibits cell proliferation and induces apoptosis of human breast carcinoma MCF-7 cells. Oncol Rep 11: 441-446, 2004.

33 Oberhammer F, Wilson JW, Dive C, Morris ID, Hickman JA, Wakeling AE, Walker PR and Sikorska M: Apoptotic death in epithelial cells: cleavage of DNA to $300 \mathrm{and} /$ or $50 \mathrm{~kb}$ fragments prior to or in the absence of internucleosomal fragmentation. EMBO J 12: 3679-3684, 1993.

34 Stewart ZA, Westfall MD and Pietenpol JA: Cell-cycle dysregulation and anticancer therapy. Trends Pharmacol Sci 24: 139-145, 2003.

35 Landberg G and Roos G: The cell cycle in breast cancer. APMIS 105: 575-589, 1997.

36 Vermeulen K, Berneman ZN and Van Bockstaele DR: Cell cycle and apoptosis. Cell Proliferation 36: 165-175, 2003.

37 Landberg G, Nielsen NH, Nilsson P, Emdin SO, Cajander J and Roos G: Telomerase activity is associated with cell cycle deregulation in human breast cancer. Cancer Res 57: 549-554, 1997.
38 Krol J, Francis RE, Albergaria A, Sunters A, Polychronis A, Coombes RC and Lam EW: The transcription factor FOXO3a is a crucial cellular target of gefitinib (Iressa) in breast cancer cells. Mol Cancer Ther 6: 3169-3179, 2007.

39 Zhou X, Zheng M, Chen F, Zhu Y, Yong W, Lin H, Sun Y and Han X: Gefitinib inhibits the proliferation of pancreatic cancer cells via cell cycle arrest. Anat Rec (Hoboken) 292: 1122-1127, 2009.

40 Joe AK, Liu H, Suzui M, Vural ME, Xiao D and Weinstein IB: Resveratrol induces growth inhibition, S-phase arrest, apoptosis, and changes in biomarker expression in several human cancer cell lines. Clin Cancer Res 8: 893-903, 2002.

41 West JD and Marnett LJ: Endogenous reactive intermediates as modulators of cell signaling and cell death. Chem Res Toxicol 19: 173-194, 2006.

42 Hill M, Pereira V, Chauveau C, Zagani R, Remy S, Tesson L, Mazal D, Ubillos L, Brion R, Asghar K, Mashreghi MF, Kotsch K, Moffett J, Doebis C, Seifert M, Boczkowski J, Osinaga E, and Anegon I: Heme oxygenase-1 inhibits rat and human breast cancer cell proliferation: mutual cross inhibition with indoleamine 2, 3-dioxygenase. FASEB J 19: 1957-1968, 2005.

43 Queiroz EAIF, Puukila S, Eichler R, Sampaio SC, Forsyth HL, Lees SJ, Barbosa AM, Dekker RH, Fortes ZB and Khaper N: Metformin Induces Apoptosis and Cell Cycle Arrest Mediated by Oxidative Stress, AMPK and FOXO3a in MCF-7 Breast Cancer Cells. PLoS One 9: e98207, 2014.

44 WHO: Latest world cancer statistics (http://www.iarc.fr/en/ media-centre/pr/2013/pdfs/pr223_E.pdf). The International Agency for Research on Cancer 2013.

45 Cao X-h, Wang A-h, Wang C-1, Mao D-z, Lu M-f, Cui Y-q and Jiao R-z: Surfactin induces apoptosis in human breast cancer MCF-7 cells through a ROS/JNK-mediated mitochondrial/ caspase pathway. Chem Biol Interact 183: 357-362, 2010.

46 Karadedou CT, Gomes AR, Chen J, Petkovic M, Ho K-K, Zwolinska AK, Feltes A, Wong SY, Chan KY and Cheung Y-N: FOXO3a represses VEGF expression through FOXM1dependent and-independent mechanisms in breast cancer. Oncogene 31: 1845-1858, 2012.

47 Chong ZZ, Li F and Maiese K: Group I metabotropic receptor neuroprotection requires Akt and its substrates that govern FOXO3a, Bim, and $\beta$-catenin during oxidative stress. Curr Neurovasc Res 3: 107, 2006.

48 Chong $\mathrm{Z}$ and Maiese K: Erythropoietin involves the phosphatidylinositol 3-kinase pathway, 14-3-3 protein and FOXO3a nuclear trafficking to preserve endothelial cell integrity. Br J Clin Pharmacol 150: 839-850, 2007. 